\title{
Influence of the Embryonic Preplate on the Organization of the Cerebral Cortex: A Targeted Ablation Model
}

\author{
Y. Xie, ${ }^{1}$ E. Skinner, ${ }^{1}$ C. Landry, ${ }^{2}$ V. Handley, ${ }^{1}$ V. Schonmann, ${ }^{1}$ E. Jacobs, ${ }^{1}$ R. Fisher, ${ }^{1}$ and A. Campagnoni ${ }^{1}$ \\ ${ }^{1}$ Developmental and Molecular Neuroscience Group, Neuropsychiatric Institute, University of California at Los Angeles, \\ School of Medicine, Los Angeles, California 90024-1759, and ${ }^{2} P$ sychiatric Institute, University of Wisconsin, Madison, \\ Wisconsin 53719
}

Transgenic mice were generated to permit the targeted ablation of cortical preplate cells at the time they are born. In these mice, the $1.3 \mathrm{~kb}$ golli promoter of the myelin basic protein gene was used to drive the herpes simplex virus thymidine kinase (TK) transgene in cortical preplate cells. Heterozygous transgenic pairs were bred, and pregnant dams were treated with ganciclovir at embryonic days 11-12 to ablate preplate cells at the time the preplate was forming. This paradigm exposed control $(\mathrm{TK}-)$ and experimental $(\mathrm{TK}+)$ littermates to exactly the same conditions. Embryological ablation of preplate cells led to an early disruption of the radial glial framework and subplate structure in the developing cortex and dramatically altered the cellular lamination and connectivity of the cortical plate. The disturbed radial glial network contributed to an impaired radial migration of neurons into the cortical plate from the ventricular

The cortical preplate is believed to play an important role in the formation of the cerebral cortex, and it has been the subject of considerable investigation. Early neurons proliferating within the neuroepithelial zone migrate into restricted quadrants of the telencephalic vesicle to form the cortical primordial plexiform layer, or preplate, between embryonic day 11 (E11) and E13 in the mouse. Subsequently, at approximately E14, newly born neurons migrate along radial glial fibers from the ventricular zone (VZ) into the transient preplate structure. During this process, they split the preplate into a peripheral marginal zone (MZ), destined to become cortical layer I, and a deep intermediate zone (IZ), destined to become the cortical subplate. They occupy a new layer between these two zones to form the cortical plate (CP) (Bayer et al., 1991; Allendoerfer and Schatz, 1994; Marin-Padilla, 1998). The morphogenetic sequence of early cortical organization and other studies suggest strongly that Cajal-Retzius cells destined for the MZ play important roles in the proper cellular lamination of the CP (Sheppard and Pearlman, 1997; Meyer et al., 2000). Subplate neurons play key roles in the formation of axonal connections within the $\mathrm{CP}$, between hemispheres and between the CP and subcortical sites (Wood et al., 1992; Allendoerfer and Shatz, 1994; Soriano et al., 1994; Molnar and Blakemore, 1995; Molnar et al., 1998; Super et al., 1998; Del Rio et al., 2000).

\footnotetext{
Received April 2, 2002; revised May 23, 2002; accepted June 18, 2002.

This work was supported by National Institutes of Health Grants NS 33091 and NS 23022.

Correspondence should be addressed to Dr. A. T. Campagnoni, Room 47-448, Neuropsychiatric Institute, University of California at Los Angeles, School of Medicine, 760 Westwood Plaza, Los Angeles, CA 90024. E-mail: acampagnoni@mednet.ucla.edu. Copyright (C) 2002 Society for Neuroscience $0270-6474 / 02 / 228981-11 \$ 15.00 / 0$
}

zone. The cortical plate became dyslaminated, and there was a substantial reduction in short- and long-range cortical projections within the cortex and to subcortical regions. Cell death within the cortical plate and the proliferative zones was substantially increased in the ablated animals. After birth, a cortical lesion developed, which became exacerbated with the secondary onset of hydrocephaly in the second postnatal week. The results underscore the critical importance of the preplate in cortex formation, mediated through its guidance of the formation of radial glial scaffolding, subsequent neuronal migration into the incipient cortical plate, and the final arrangement of its vertical organization and cellular connectivity.

Key words: preplate; cortex; development; transgenic; $\beta$-galactosidase; HSV-thymidine kinase; ablation; cell death

An attractive approach to test the role of preplate cells in cortical development is to ablate them at very early stages and then examine the consequences of the ablation on cortical development. A variety of methods, including irradiation (Roper, 1998), mitotic inhibition (Noctor et al., 1999), and excitatory cytotoxicity (Ghosh and Shatz, 1993; Lein et al., 1999), have been used to examine the role and function of preplate neurons during early cortical development. Although informative, these approaches are relatively nonspecific, and there can be significant individual variation in experimental animals with these techniques. A genetic ablation model with a specifically targeted "suicide" gene would offer advantages with respect to targeting of an appropriate cell population and consistency of results from animal to animal.

To investigate the role of the preplate in the formation of the cortex, we generated transgenic mice using the golli promoter of the myelin basic protein (MBP) gene to drive expression of the herpes simplex virus thymidine kinase (HSV-TK) gene. We showed previously that this promoter targets $\beta$-galactosidase $(\beta$ gal) (lacZ) expression to the cortical preplate and to subplate neurons and Cajal-Retzius cells (Landry et al., 1998). Proliferative cells expressing HSV-TK convert ganciclovir to a toxic nucleotide analog that inhibits DNA synthesis and causes cell death (Moolten, 1986). We used this experimental approach to selectively and substantially ablate neurons in the cortical preplate at E11-E12 while following the subsequent morphogenesis of the cortical plate. Based on previous reports, these experiments were designed to test the hypothesis that a significant reduction in the cortical preplate (and thus its MZ and subplate derivatives) would 
impair developmental organization of the cortical plate as evidenced by both cellular and axonal dyslamination.

\section{MATERIALS AND METHODS \\ Generation of golli-HSV-TK transgenic mice}

\section{Construction of the vector for golli-TK transgenic line}

The golli-TK plasmid was created by first cloning the $1.3 \mathrm{~kb} E c o$ RIBam HI fragment of the golli promoter into EcoRI-BamHI site of pGEM3Zf - (Promega, Madison, WI). Then the $1.8 \mathrm{~kb}$ thymidine kinase gene from pMK' (Stuart et al., 1984) was excised with BgIII and $P v u I I$ and inserted into the BamHI-HincII sites of the promoter pGEM3Zfplasmid. The completed construct was digested with EcoRI and SacII, and the promoter plus thymidine kinase was isolated by gel electrophoresis. Production of the transgenic founders was performed by the University of California, Los Angeles Transgenic Core Facility (Los Angeles, CA).

\section{Founders}

Transgenic mouse lines were identified by Southern blot analyses on BSTEII digests of isolated tail DNA using a probe specific for exon 1 of the golli-MBP gene. The insertion of a single copy of the golli-TK transgene was determined using Southern blot analyses to compare the intensities of the hybridization signals of the TK probe with those from a probe of a known single copy gene, MBP. The double-transgenic golli-TK/lacZ mice were generated by crossing hemizygous $(\mathrm{TK} /+)$ mice to transgenic mice $\left(1 \mathrm{E}^{2}\right)$ homozygous for the $\beta$-galactosidase gene under the control of the same $1.3 \mathrm{~kb}$ golli-specific promoter (Landry et al., 1998). Southern blot analyses of the double-transgenic DNA, probed with RB2121 (exon 1 of the golli-MBP gene) yielded a $1.0 \mathrm{~kb}$ band from the native golli gene, a $2.9 \mathrm{~kb}$ band from the TK transgenic, and 6.4, 7.2, and $9.0 \mathrm{~kb}$ bands from the $1 \mathrm{E}^{2}$ transgenic.

\section{Analysis of the transgenic mice Genotyping by PCR}

The golli-TK transgene was identified by PCR using the MGTB sense primer (within golli-MBP promoter) 5'-CTGAGCTTCACGACCCCGGAACATAGT and the TK3P antisense primer 3'-GTCATGCTGCCCATAAGGTATCGCG. The double-transgenic mice (golli-TK/lacZ) were identified using the MGTB sense primer and the $\beta$-gal antisense primer 3'-CTCATCCGCCACATATCCTGATCTTCC. For PCR amplification, a $25 \mu \mathrm{l}$ reaction was assembled that contained $200 \mathrm{ng}$ of genomic DNA, 10 pmol of each primer, $4 \mathrm{~mm} \mathrm{MgCl}_{2}, 0.2 \mathrm{~mm}$ dNTPs, PCR buffer, and $1.25 \mathrm{U}$ of Taq DNA polymerase (Invitrogen, Carlsbad, CA). The cycling conditions were as follows: (1) denaturation at $94^{\circ} \mathrm{C}$ for $4 \mathrm{~min}$; (2) $94^{\circ} \mathrm{C}$ for $1 \mathrm{~min}, 70^{\circ} \mathrm{C}$ for $45 \mathrm{sec}$, and $72^{\circ} \mathrm{C}$ min for 40 cycles; and (3) one cycle at $72^{\circ} \mathrm{C}$ for $7 \mathrm{~min}$ on a PerkinElmer Life Sciences (Emeryville, CA) 480 thermal cycler. PCR products were then analyzed on a $1 \%$ agarose Tris-acetic acid-EDTA gel. The TK product was $600 \mathrm{bp}$, and the $\beta$-gal product was $1.1 \mathrm{~kb}$.

\section{Drug treatment}

Ganciclovir (Cytovene-IV tm; Roche Laboratories, Nuffy, NJ) was prepared at $0.25 \mathrm{mg} / \mathrm{ml}$ in sterile water. Timed-pregnant females were given intraperitoneal injections of ganciclovir $(20 \mu \mathrm{g} / \mathrm{gm})$ on E11 and E12 (day of insemination, day 0.5$)$. Two injections $(\sim 8-12 \mathrm{hr}$ apart) were given each day. In some experiments, ganciclovir was administered by two injections on each E16-E17 and E17-E18 and two injections on each E16, E17, and E18.

\section{Tissue preparation}

Postnatal day 1 (P1), P7, and P14 animals were anesthetized with halothane (Halocarbon Laboratories, North Augusta, SC) and perfused intracardially with $4 \%$ paraformaldehyde in PBS. For embryonic time points (E11-E18), timed-pregnant females were anesthetized and killed by cervical dislocation. Embryos were removed, and the brains were dissected. All tissues were postfixed either overnight or for $1 \mathrm{hr}$ (histochemistry) with the $4 \%$ paraformaldehyde in PBS. The fixed tissue was then cryoprotected in sucrose, frozen in OCT, and sectioned $(20 \mu \mathrm{m})$. Sections were mounted on Superfrost Plus slides (Fisher Scientific, Pittsburgh, PA) and processed for histochemical and immunohistochemical examination.

\section{$\beta$-Galactosidase staining}

Frozen sections were removed from $-80^{\circ} \mathrm{C}$ freezer, air dried, and rinsed in a solution containing $0.01 \%$ sodium deoxycholate, $0.02 \%$ NP- $40,2 \mathrm{~mm}$

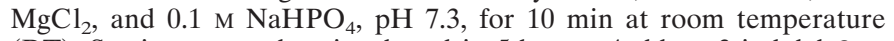
(RT). Sections were then incubated in 5-bromo-4-chloro-3-indolyl- $\beta$-Dgalactoside (X-gal) stain solution $\left[2 \mathrm{mM} \mathrm{MgCl}_{2}, 5 \mathrm{mM} \mathrm{K}_{3} \mathrm{Fe}(\mathrm{CN})_{6}\right.$, and 5 $\mathrm{mm} \mathrm{K}_{4} \mathrm{Fe}(\mathrm{CN})_{6}$ plus $0.1 \mathrm{M} \mathrm{NaHPO}_{4}$, $\mathrm{pH} 7.3,0.01 \%$ sodium deoxycholate, $0.02 \% \mathrm{NP}-40$, and $8 \mathrm{mg} / \mathrm{ml} \mathrm{X}$-gal] for $6-16 \mathrm{hr}$ at $37^{\circ} \mathrm{C}$. Washing the sections in PBS stopped the X-gal histochemical reaction.

\section{Immunohistochemistry}

Frozen sections were air dried and rinsed in PBS before all immunohistochemical procedures. For immunofluorescence, sections were incubated in $2 \%$ BSA in $0.1 \mathrm{M}$ PBS and $0.03 \%$ Triton X-100 for $1 \mathrm{hr}$ at RT to block nonspecific staining. The sections were then incubated with the primary antibody at $4^{\circ} \mathrm{C}$ for $48-72 \mathrm{hr}$. Bound primary antibody was detected by incubation with the appropriate secondary antibody labeled with fluorescein (FITC) or Texas Red (1:200; Jackson ImmunoResearch, West Grove, PA) for 1-2 hr at RT. After washing in PBS, the slides were coverslipped in Aquamount and analyzed with a Leica (Nussloch, Germany) DMR microscope. A similar protocol was followed for immunohistochemistry with biotinylated secondary antibodies except that, before blocking, the sections were treated with $0.3 \% \mathrm{H}_{2} \mathrm{O}_{2}$ in methanol to quench endogenous peroxidase activity. After incubation with the appropriate secondary antibody, the avidin-biotin-peroxidase system (Vectastain Elite ABC) was used as recommended by the manufacturer (Vector Laboratories, Burlingame, CA) and developed in DAB color solution. The sections were then dehydrated, cleared, and coverslipped with Permount.

The following antibodies were used in this study: polyclonal rabbit anti- $\beta$-galactosidase (Chemicon, Temecula, CA), 1:2000; polyclonal antigolli (Landry et al., 1996), 1:3000; polyclonal rabbit anti-HSV-TK serum (gift from Dr. M. Sofroniew, University of California at Los Angeles, Los Angeles, CA), 1:2000; monoclonal mouse anti-nestin (clone 401; PharMingen, San Diego, CA), 1:1000; polyclonal rabbit antineurofilament-M (NF-M) (Chemicon), 1:200; monoclonal mouse antiRC2 (Developmental Studies Hybridoma Bank, University of Iowa, Iowa City, IA); and polyclonal rabbit anti-somal-restricted proteolipid protein (srPLP) (Bongarzone et al., 2000), 1:1000.

\section{Bromodeoxyuridine birth dating and detection}

Timed-pregnant female mice were given intraperitoneal injections of 100 $\mu \mathrm{g} / \mathrm{gm}$ body weight of 5-bromo-2'-deoxyuridine (BrdU) in sterile PBS. After BrdU injection, pups were harvested at specific ages, and the brains were processed as described above. Cryostat sections were incubated in $2 \mathrm{~N} \mathrm{HCl}$ for $30 \mathrm{~min}$ at $37^{\circ} \mathrm{C}$, rinsed in $0.1 \mathrm{M}$ sodium borate, $\mathrm{pH} 8.3$, and then incubated overnight with anti-BrdU monoclonal antibody (Becton Dickinson, San Jose, CA) at 1:100. Detection of the antibody was performed as described above.

\section{Terminal deoxynucleotidyl transferase-mediated biotinylated UTP nick end labeling in situ detection procedures}

Frozen sections were air dried, rinsed in PBS, and incubated in $0.3 \%$ $\mathrm{H}_{2} \mathrm{O}_{2}$-methanol solution to block endogenous peroxidase activity. Cell permeability was increased by incubating the sections in $0.1 \%$ Triton $\mathrm{X}-100$ in $0.1 \%$ sodium citrate for $2 \mathrm{~min}$ on ice at $4^{\circ} \mathrm{C}$. The sections were rinsed in PBS and incubated with the terminal deoxynucleotidyl transferase-mediated biotinylated UTP nick end labeling (TUNEL) reaction mixture for $1 \mathrm{hr}$ at $37^{\circ} \mathrm{C}$ [In Situ Cell Death Detection Kit; peroxidase (POD); Roche, Indianapolis, IN]. The sections were then examined with epifluorescence or treated with the Convertor-POD reagent and peroxidase substrate according to the instructions of the manufacturer (Roche).

\section{Quantitative measurements}

Cortical thickness. E18, P1, and P4 control and ablated brains (five to nine brains in each age) were used for this analysis. Coronal sections of constant thickness $(20 \mu \mathrm{m})$ were taken rostrally, starting from the lateral ventricle. Every sixth section was transferred to a slide, yielding a total of 15 sections per brain (with each $n$ equaling the pooled average of the 15 measurements per section). This sampling procedure was used in all subsequent measurements. Minimal cortical depth was measured between the pial surface and the bottom of the cortex using a $10 \times$ objective. Data were statistically analyzed with SPSS (Chicago, IL) software. 

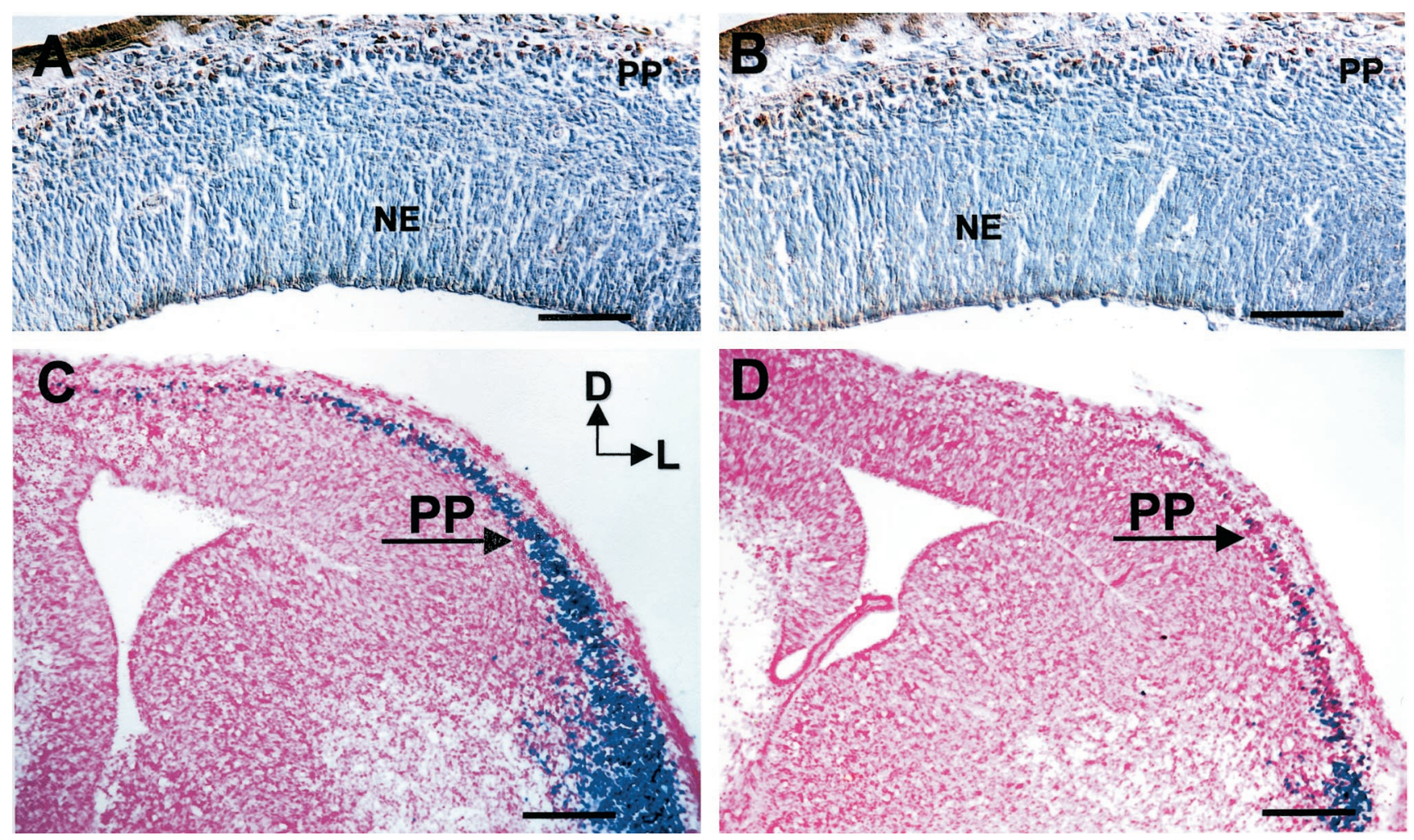

Figure 1. Cortical preplate neurons genetically targeted for ablation and the early impact of genetic ablation on embryonic cerebral cortex. $A$, $B$, Photomicrographs of preplate target neurons containing brown immunoreactivity for $\beta$-galactosidase $(A)$ and the HSV-TK $(B)$ in the cerebral cortical quadrant of the telencephalic vesicle in E13 mice. $P P$, Preplate; $N E$, neuroepithelial proliferative zone. Tissue sections were counterstained with cresyl violet. Note the fidelity of the patterns of expression of the transgenes demonstrated by the equivalent types and locations of the labeled cells. $C$, $D$, Photomicrographs of preplate neurons containing blue $\mathrm{X}$-gal reaction product indicative of the expression of the $\mathrm{Z}$ transgene in coronal tissue sections from the telencephalic vesicles of wild-type control $(C)$ and littermate double-transgenic $(D)$ mice at age E13. $P P$, Preplate; $D$, dorsal; $L$, lateral. Tissue sections were counterstained with nuclear fast red. Note the reduction in the numbers of blue cells in the telencephalton-ablated animal. Scale bars: $A$, $B, 40 \mu \mathrm{m} ; C, D, 160 \mu \mathrm{m}$.

BrdU-labeled cells. Pregnant mice at E15 were injected with BrdU, and embryonic brains of control $(n=5)$ and ablated $(n=8)$ pups were harvested $1.5 \mathrm{hr}$ after injection. BrdU-labeled cells in each section were counted within a $6.0 \times 10^{-2} \mathrm{~mm}^{2}$ cortical area with a $40 \times$ objective in similar brain regions for all animals. The percentage of the total number of BrdU-labeled cells found within the intermediate zone and cortical plate was calculated, and statistical analysis was made using SPSS software.

TUNEL-labeled nuclei. E15, E18, and P1 control and ablated brains (8-12 brains in each age) were used for this quantitative analysis. TUNEL-labeled nuclei in each section were counted in a $2.4 \times 10^{-1}$ $\mathrm{mm}^{2}$ cortical area with a $20 \times$ objective in a similar brain region for all animals. The numerical density of TUNEL-labeled nuclei in a given cortical area was calculated, and statistical analyses were performed with SPSS software.

\section{RESULTS}

\section{Generation of a transgenic mouse that expresses HSV- TK in cortical preplate and subplate neurons}

We identified previously a promoter element in the myelin basic protein gene capable of targeting $\beta$-galactosidase to cortical preplate and subplate neurons (Landry et al., 1998). The promoter element consisted of a fragment containing $1.1 \mathrm{~kb}$ upstream of the golli transcription start site plus $0.2 \mathrm{~kb}$ downstream into the first exon of the gene. In this study, we used this promoter element to drive HSV-TK in preplate cells to permit their ablation with ganciclovir early in preplate formation. For these experiments, heterozygous (i.e., $\mathrm{TK} /+$ ) parents were used to generate $\mathrm{TK}+$ mice and their $\mathrm{TK}-$ controls within the same litter, thereby exposing the control $(\mathrm{TK}-)$ pups to exactly the same ganciclovir conditions as the $\mathrm{TK}+$ pups in all experiments. Animals were individually genotyped by PCR at the time brains were collected and prepared for analysis. No differences were observed in the phenotype of the homozygous and heterozygous TK + animals exposed to ganciclovir treatment, suggesting that there was sufficient TK expression in the preplate cells of the heterozygous animals to permit their ablation.

Previously, we established the specificity of the golli promoter using golli-lacZ mice (Landry et al., 1998). So we compared expression of the golli promoter-driven HSV-TK with lacZ by generating $\mathrm{TK} /$ lacZ double transgenics and determining whether there was coexpression of the two transgenes under the golli promoter. We examined expression of the transgenes from E12 to early postnatal ages. Coexpression of lacZ and TK was observed as early as E12 in the cortical preplate and subplate of the double-transgenic mice. Expression of TK and lacZ also was seen in the DRGs, spinal cord, and parts of the olfactory system as reported previously in the lacZ mice (Landry et al., 1998). Figure 1 shows the immunocytochemical expression of lacZ (Fig. 1A) and TK (Fig. $1 B$ ) in adjacent sagittal sections within the cortical region of E13 mice. Expression of both transgenes was evident in the preplate zone. The apparent TK immunoreactivity at the pial surfaces and subventricular edges in Figure 1 is artifactual. Double-labeling experiments using X-gal to identify lacZ transgene expression and anti HSV-TK to establish TK expression 
indicated that there was complete overlap of expression of the two transgenes at the individual cell level in the cortical preplate (data not shown). The results indicated that the golli promoter targeted TK to the cortical preplate of the developing mouse brain. Analysis of TK expression at later ages mirrored the expression of the lacZ, indicating that the promoter was targeting both transgenes to the expected cells.

We wanted to take advantage of the toxicity of ganciclovir to kill TK-expressing cells at an early stage in cortical development, during formation of the cortical preplate and the birth of cortical pioneer neurons. The drug kills dividing cells and it is cleared from the system within hours, so we administered ganciclovir by four injections over E11 and E12. As shown in coronal views in Figure 1, $C$ and $D$, this resulted in a significant loss of lacZexpressing preplate neurons. Note that the lateral regions, in which the preplate first develops, were relatively less affected than the midline regions, consistent with the known timing and progression of preplate neurogenesis. Although not shown, we also observed a substantial reduction in calretinin + Cajal-Retzius cells in the ablated animals.

\section{Histological abnormalities are evident in the development of the cortex shortly after ganciclovir treatment}

Cresyl violet histological analyses were performed on the "ablated" brains of fetuses, neonates, and early postnatal transgenic animals treated with ganciclovir at E11-E12. Histological differences in the cerebral walls between the ablated and control fetuses were evident as early as $3 \mathrm{hr}$ after the fourth injection on E12. Three-layered structures of the cerebral wall, corresponding to a neuroepithelial proliferative zone, preplate, and a subpial "marginal" layer, could be observed by this time. Compared with the controls, it also appeared that the preplate was thinner in both the lateral regions and midline regions of the ablated animals (Fig. 1, compare counterstaining in $C, D$ ).

At later ages, particularly by E18 and beyond, significant histological abnormalities were evident in the cortices of the ablated animals. Figure 2 illustrates some of these in P4 mice. It was apparent that the subplate layer was indistinct and that the cortices of the ablated mice were thinner and dyslaminated. The cortical disorganization of the ablated mouse made it difficult to assign layers. Cellularity in layers V-VI appeared to be significantly reduced, and the presence of prominent pyramidal neurons in layer $\mathrm{V}$ of controls was not evident in the ablated cortex. We saw no evidence of heterotopia in the ablated cortices.

Other alterations in the brains of the ablated animals included a malformed corpus callosum and increased ventricular size. At $\mathrm{P} 4$, the incipient white matter region between gray matter and the ventricle was much narrower in the ablated brain than that of controls, and, by P7, the corpus callosum in the ablated mice, located beneath the neocortical subplate region, was very thin. Slightly larger lateral ventricles were evident in the ablated mice by late embryonic and neonatal life, and these continued to enlarge with age.

Other structures within the brain did not appear to be affected by the ganciclovir treatment. Unlike the neocortex, the regional topology of other forebrain structures of the ablated brain, such as the striatum and septum, was intact. Interestingly, cortico-fugal fiber tracts running through the striatum were significantly smaller in diameter, consistent with the perturbed subplate cells and their role in pioneering these connections. Similarly, there

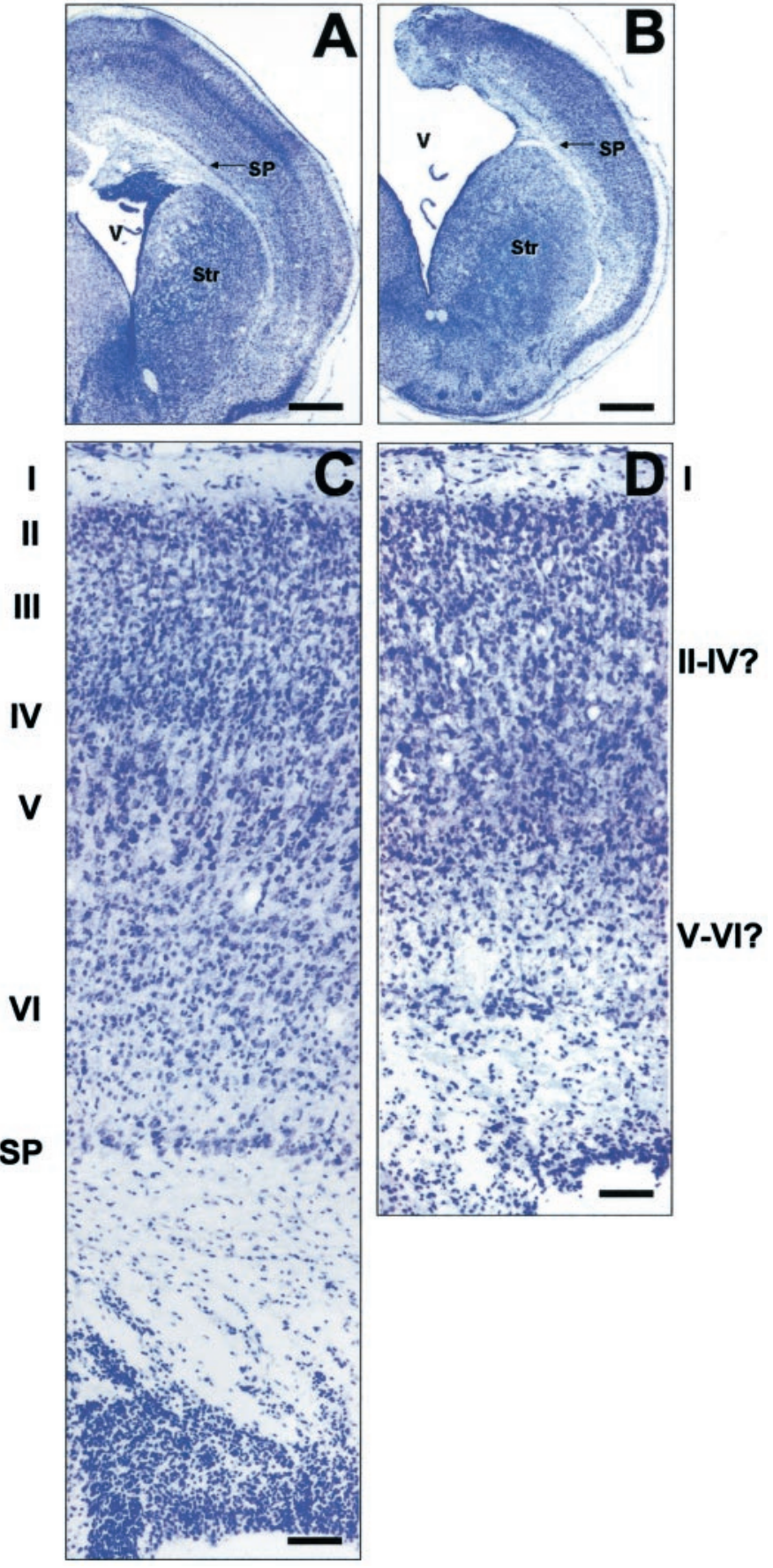

Figure 2. Cresyl violet staining of control $(\mathrm{TK}-)$ and ablated $(\mathrm{TK}+)$ brains at P4. $A, B$, Low-power views of the regional organization of forebrains of wild-type control $(A)$ and ablated TK + transgenic $(B)$ mice. $V$, Lateral ventricle; Str, striatum; $S P$, cortical subplate. Note the stunted cerebral cortex, cellular dyslamination, and enlarged lateral ventricle produced in the ablated TK+ animal. Subcortical "white matter" fiber tracts are also dramatically thinner in the ablated mouse than in its control. $C, D$, Vertical organization of cerebral cortex of wild-type $(A)$ and ablated $(B)$ mice. $I-V I$, Cortical layers 1-6; SP, cortical subplate. Note the indistinct lamination, reduced cellularity, and diminished thickness of the cerebral cortex of the ablated mouse compared with homologous cortical sites in its littermate control. The subcortical white matter of the corpus callosum and corona radiata is also thinned in the ablated mouse. Scale bars: $A, B, 160 \mu \mathrm{m} ; C, D, 40 \mu \mathrm{m}$. 

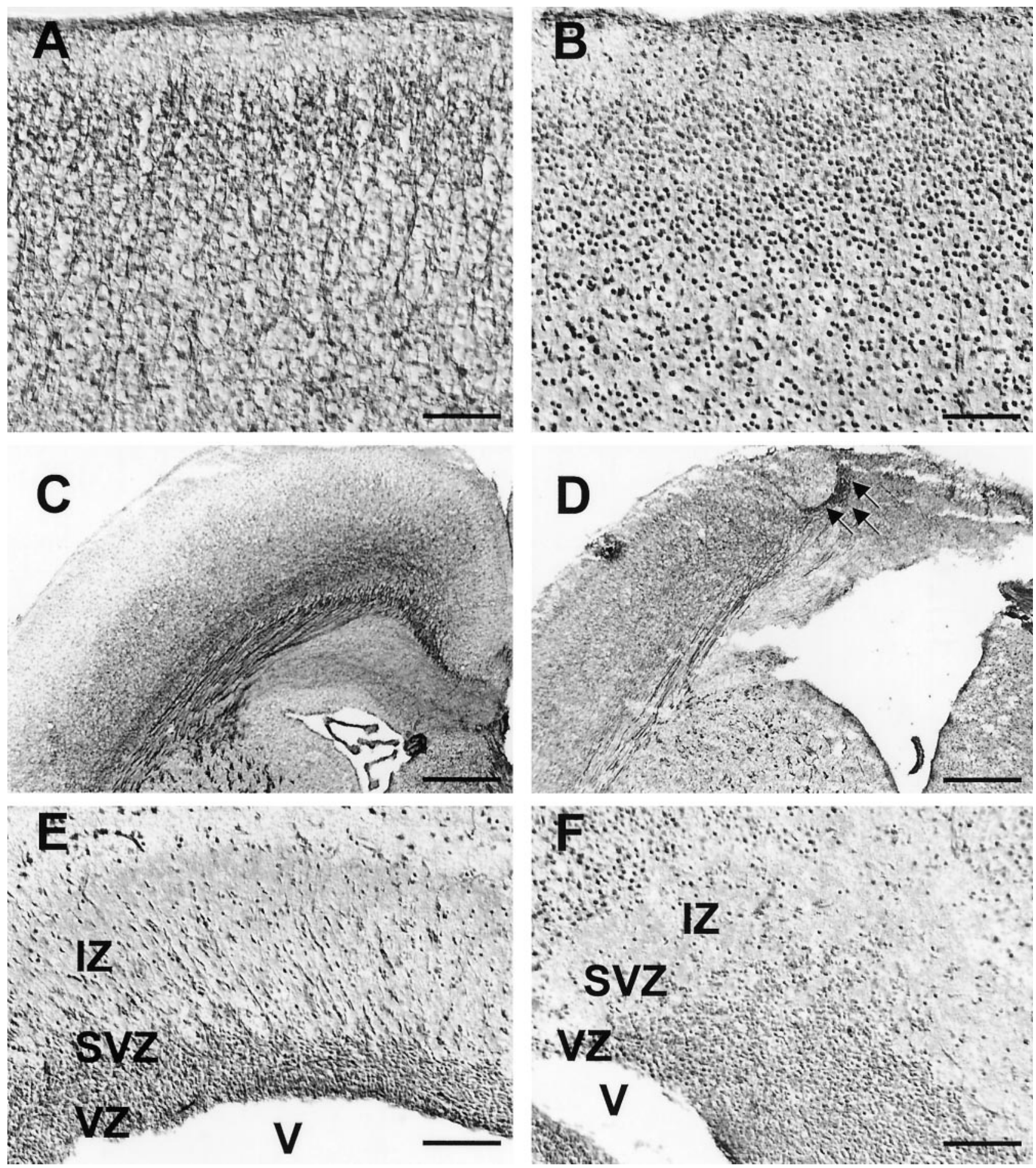

Figure 3. Evidence of fiber reduction-misdirection and cellular abnormalities in the ablated cerebral cortex at P1. $A, C, E$, Wild-type control mice; $B$, $D, F$, ablated littermate mice. $A, B$, Photomicrographs of golli protein immunoreactivity in wild-type and transgenic ablated mice. Note the near-complete absence of golli-like immunoreactivity in the ablated cortex. $C, D$, Photomicrographs of the NF-M immunoreactivity in wild-type and ablated mice. Note the substantial reduction of NF-M expression in the subcortical white matter structures of the corona radiata, corpus callosum, and internal capsule of the ablated brain. Abnormal Probst bundles (see arrows) were also observed in the cingulate cortex of the ablated animals. $E, F$, Photomicrographs of srPLP immunoreactivity in wild-type and transgenic ablated mice. Note that strings of srPLP-immunoreactive cells found in the intermediate and subventricular zones of the control case were disrupted in the ablated animals. $V$, Lateral ventricle. Scale bars: $A, B, E, F, 40 \mu \mathrm{m} ; C, D, 80 \mu \mathrm{m}$.

was a clear correlation of the affected areas of the ablated brains with the timing of cortical development.

Treatment of pregnant females with ganciclovir at middle to late embryonic stages in cortical development (e.g., E16, E17, and E18) resulted in no obvious histological abnormalities as late as $28 \mathrm{~d}$ of age (data not shown). Thus, the formation of the lesion correlated with ganciclovir treatment during genesis of the cortical preplate and the birth of subplate neurons in the mouse brain. 

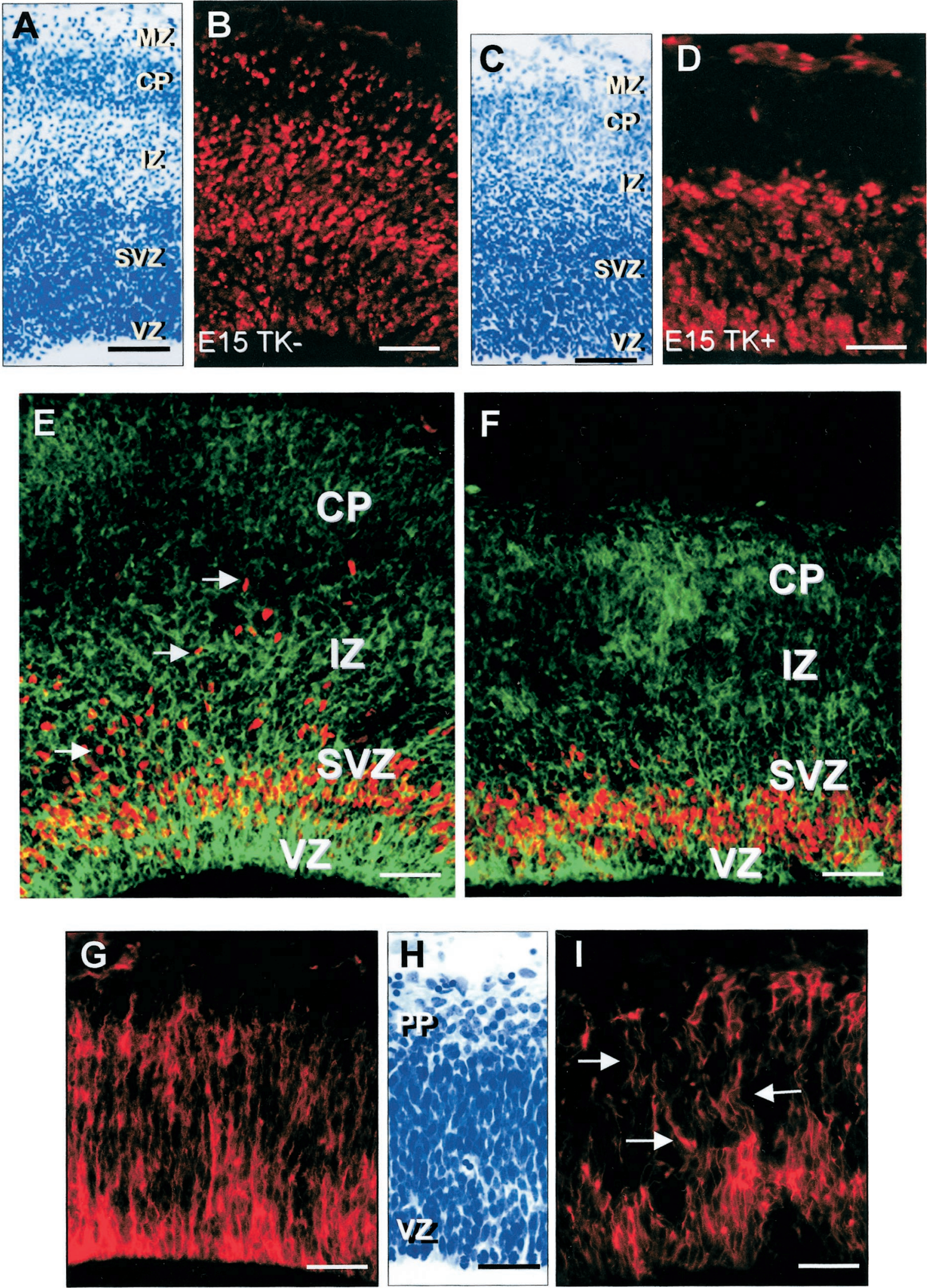

Figure 4. Morphological evidence for impaired neuronal migration and disrupted radial glial fiber in ablated animals. $A-D$, After ganciclovir treatment, dams were injected with BrdU at E13 and analyzed $48 \mathrm{hr}$ later (E15). In control $(B)$ and ablated $(D)$ brains, BrdU was detected immunohistochemically (red), and adjacent sections were stained with cresyl violet. Numerous BrdU-labeled cells had migrated into the CP and IZ by this time in the control, but significantly fewer cells had migrated to these regions in the ablated brains. $E, F$, E15 animals were injected with BrdU, and the distribution of labeled cells was compared after $1.5 \mathrm{hr}$ in control and ablated brains. Again, migration into the upper layers was much more apparent in (Figure legend continues.) 


\section{Immunohistochemical studies confirm the histological findings and reveal other abnormalities in the ablated $(\mathrm{TK}+)$ brains}

Additional evidence of abnormal cortical organization was obtained by immunostaining with several neuronal markers, including NF-M, golli proteins, and srPLP. In postnatal brain, golli antibody stains fibers as well as cell bodies within the cortex. As shown in Figure 3, $A$ and $B$, golli+ fiber staining in the cortex is significantly reduced in the ablated brain. Compared with the controls (Fig. $3 A$ ), a significant reduction in density of neuronal fibers stained for golli proteins was observed in the upper cortical layers (II-IV) of the ablated brains (Fig. 3B). In view of the fiber loss revealed by golli immunostaining, we also examined the ablated animals by immunostaining for NF-M. Figure 3, $C$ and $D$, shows staining of a portion of the P1 cortex, close to the midline, with anti-NF-M. Again, a reduction in the number of fibers was evident in the ablated brains. One of the more striking features of the NF-M staining was the appearance of Probst bundles in the cingulate cortices (Fig. 3D, arrows). Probst bundles are aggregations of fibers that derive from axons that fail to cross the midline after their initial extension to the medial hemispheric walls (das Neves et al., 1999). Interestingly, the formation of Probst bundles has been observed in the Tbr 1 knock-out mouse, in which subplate development is abnormal (Hevner et al., 2001). These results also were in agreement with the other histological data showing a thinning of the corpus callosum in the ablated brain.

Figure 3, $E$ and $F$, shows a portion of the subventricular zones (SVZs) of the control and ablated brains at P1, immunostained with anti-srPLP, a product of the myelin PLP gene expressed in neurons (Bongarzone et al., 1999). A comparison of the two panels shows the disrupted cortical organization in the ablated (Fig. $3 F$ ) compared with controls (Fig. $3 E$ ). In normal brain, it is possible to discern "strings" of cells emerging from the subventricular zone into the intermediate zone (Fig. 4E, arrows). Presumably, these are migrating neurons at this age. These strings of cells are less apparent and appear to be disrupted in the ablated cortex (Fig. $3 F$ ). These results suggested that normal neuronal migration, maturation, and cortical laminar formation were interrupted by ganciclovir treatment at E11-E12.

\section{Impairment of neuronal migration in the ablated brains}

The apparently reduced cellularity in the cerebral cortex and the apparent disruption of cells migrating out of the subventricular zone suggested the possibility that neuronal migration from the proliferative zones into the cortical plate during development might be impaired as a consequence of the ablation. To investigate this possible impairment, we performed BrdU incorporation experiments to visualize the migration of BrdU-labeled cells in control $(\mathrm{TK}-)$ and ablated $(\mathrm{TK}+)$ brains. After ganciclovir treatment at E11-E12, the dams were then injected with BrdU at E13, and animals were analyzed $48 \mathrm{hr}$ after BrdU injection. Figure $4 A-D$ shows BrdU fluorescent immunostaining of control (Fig. $4 B$ ) and ablated (Fig. 4D) cortical plate regions $48 \mathrm{hr}$ after BrdU injection, along with adjacent cresyl violet-stained sections for comparison (Fig. 4A,C). After $48 \mathrm{hr}$, when numerous BrdU- labeled cells populated the cortical plate of the controls, most of the BrdU labeling still remained within the SVZ/VZ of the ablated animals. Note that the pial surfaces of both control and ablated animals were labeled, undoubtedly attributable to dividing fibroblasts. The results suggested that neuronal migration from the SVZ/VZ was impaired in the ablated animals.

Additional evidence for impaired neuronal migration was obtained by short-term labeling of E15 mice. Figure 4 shows BrdU incorporation experiments combined with RC2 immunostaining for radial glial fibers $1.5 \mathrm{hr}$ after injection of control and ablated animals with BrdU at E15. In the E15 control brain (Fig. 4E), BrdU-labeled cells were distributed throughout the proliferative zones, intermediate zone, and even into the cortical plate. Many BrdU cells could be seen along RC2 + fibers. In contrast, in the ablated mice (Fig. $4 F$ ), the BrdU+ cells were primarily confined to the proliferative zone, and some had migrated into the intermediate zone. A quantitative assessment of these data showed that, after $1.5 \mathrm{hr}, 16.0 \pm 0.4 \%$ (mean $\pm \mathrm{SEM})$ of the labeled cells were found in the IZ or CP of the control animal, in contrast to $4.4 \pm 0.8 \%$ of the labeled cells in the ablated animals.

Also, it appeared as if the radial glial network was disrupted in the ablated animals. There appeared to be fewer radial glia, and many fibers seemed to terminate prematurely along the radial network. This is illustrated more clearly for E13 animals in Figure 4, $G$ and $H$. In this case, the radial glial fibers have been labeled in red with RC2. As can be seen, there was considerable alteration in the number and morphology of the radial glial fibers between the control $(\mathrm{TK}-)$ and ablated $(\mathrm{TK}+)$ brains. In the ablated animals, there was a reduced density of radial glial fibers, and the fibers appeared to be truncated or disrupted, in contrast to the straight and regular radial glial fibers evident in the control.

Thus, the results suggested that ablation of preplate neurons resulted in a reduction in the numbers and morphologies of the radial glia, accompanied by impaired migration of cortical neurons out of the proliferative zone into the growing cortical plate. The impaired migration could be attributable to the lack of sufficient numbers of glial fibers along which newly born neurons could migrate.

\section{Increased cell death in the cortex and SVZ/VZ of the ablated brains}

Several findings implied that cell death might be increased in the ablated cortices during embryonic and neonatal life. Impaired migration of cortical neurons from the VZ/SVZ suggested that there might be greater turnover of those cells within the VZ/SVZ. Also, the disrupted radial glial network might misdirect those neurons that did exit the VZ/SVZ within the cortical layers. This and the absence of a clear subplate could explain the loss of cortical connections and lead to the death of those neurons in the absence of synaptic activity. For these reasons, we examined TUNEL to compare cell death in the control and ablated brains. TUNEL-positive labeled nuclei were observed in the ablated animals throughout cortical development. Figure 5 shows views of control and ablated cortices at E15 (Fig. 5A,B) and P1 (Fig. $5 C, D)$ after TUNEL staining (dark brown) and cresyl violet

\section{$\leftarrow$}

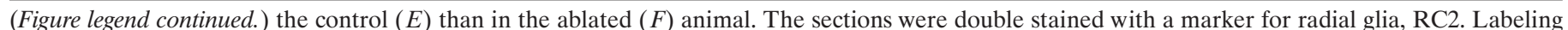

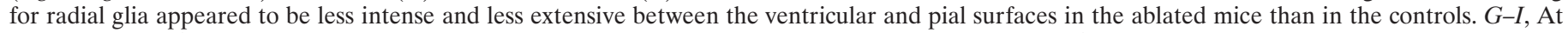

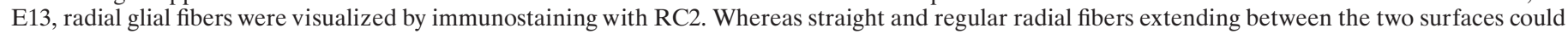

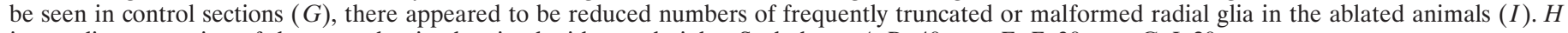
is an adjacent section of the control animal stained with cresyl violet. Scale bars: $A-D, 40 \mu \mathrm{m} ; E, F, 30 \mu \mathrm{m} ; G-I, 20 \mu \mathrm{m}$. 

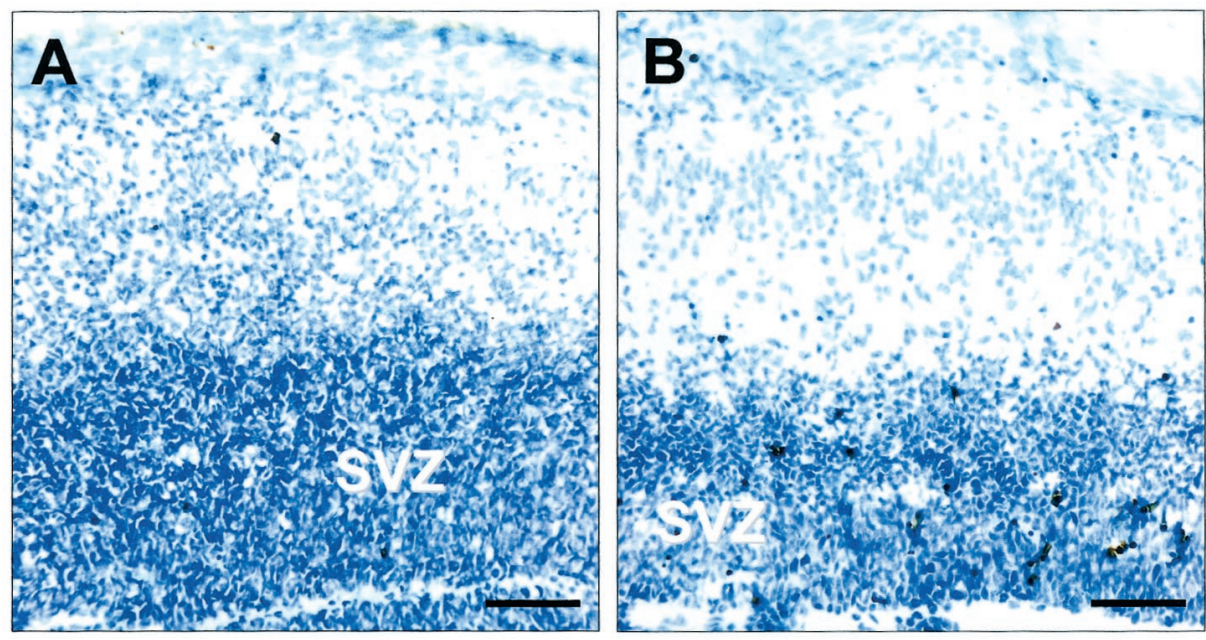

Figure 5. Evidence for increased aptotic cell death in the cerebral cortex $(C t x)$ and VZ/SVZ of ablated mice. $A, B$, Photomicrographs showing increased TUNEL+ cerebral cortical cells (brown labeling) in E15 ablated $(B)$ and littermate control $(A)$. Tissue sections were counterstained with cresyl violet. Very few apoptotic cells were found in the control brains, but increased numbers of apoptotic cells were found in the subventricular, proximal intermediate zones and cortical plate of the ablated brains. $C$, $D$, Photomicrographs of TUNEL+ and counterstained apoptotic cells at P1 (C, wild-type control mouse; $D$, ablated littermate). Aptotic labeled profiles were dispersed widely from the subventricular and ventricular zones through the cortical plate in both groups. Developmental increases in apoptotic cells were also observed in both groups, but the increase was substantially greater in the ablated than the control mice. Scale bars: $A, B, 40 \mu \mathrm{m} ; C, D, 80 \mu \mathrm{m}$.
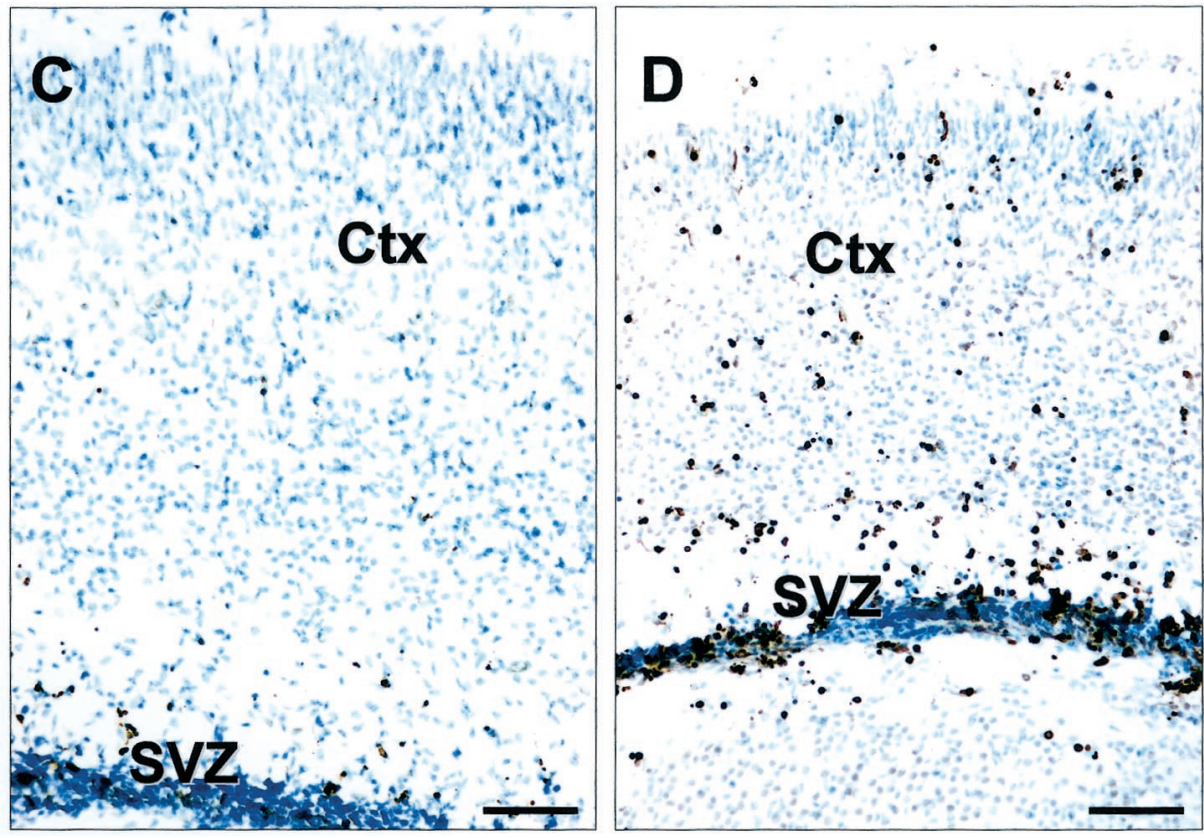

counterstaining (blue). Figure 6 shows measurements of the density of TUNEL + nuclei in the cortices of normal and ablated mice from E15 to P1. Even at E15, an increase in TUNELlabeled nuclei was evident in the SVZ/VZ of the ablated animals. Interestingly, there was a sharp increase in cell death in the SVZ/VZ and cortical plate between E18 and P1, and even more cell death throughout the cortex was observed at later ages in postnatal ablated animals. Figure 5 illustrates the substantial increase in TUNEL+ nuclei (dark brown) throughout the cortical plate and the SVZ in the ablated animal (Fig. 5D) compared with control (Fig. 5C) at P1. In the ablated animals the TUNELlabeled nuclei appeared in clusters of variable size at P1. Thus, during embryonic development, increased cell death occurred within the VZ/SVZ of the ablated mice, and, at older ages, this increased cell death continued within this proliferative zone but extended to the cortical plate as well.

\section{End-stage lesions develop in the postnatal animals}

$\mathrm{TK}+$ pups born to dams treated with ganciclovir at E11-E12 were examined at many ages postnatally. During late embryonic life, the thickness of the cortex of the ablated animals was decreased relative to controls. This is illustrated in Table 1 in which cortical thickness for control and ablated mice is given for several ages in late embryonic and early postnatal life. This difference became more apparent, even on visual inspection, at later ages. After the first postnatal week, the ablated animals developed large cortical lesions that increased in size with age. Figure 7 illustrates the extent of these lesions in a comparison of Nisslstained sagittal views of P14 and P20 TK + brains. Note the massive cortical lesion at P20 and the thinned cortex of the ablated mice. Enlarged ventricles and decreased cortical thickness are clearly evident. By P24-P28, when the animals died, very little cortex remained in the $\mathrm{TK}+$ brains.

At approximately P10, the ablated pups appeared to become mildly hydrocephalic, as indicated by ventricular expansion and, in some cases, increased head size, which increased in severity with age. The enlarged ventricles and degenerated cortex was a constant feature of all ablated animals, but the incidence of increased head size was variable. In some cases, we found ablated animals with larger and smaller head sizes than the controls within the same litter. This supports the notion that the observed postnatal hydrocephaly is secondary to the degeneration of the cortex. The data in Figures 5 and 6 indicate that increased cell 


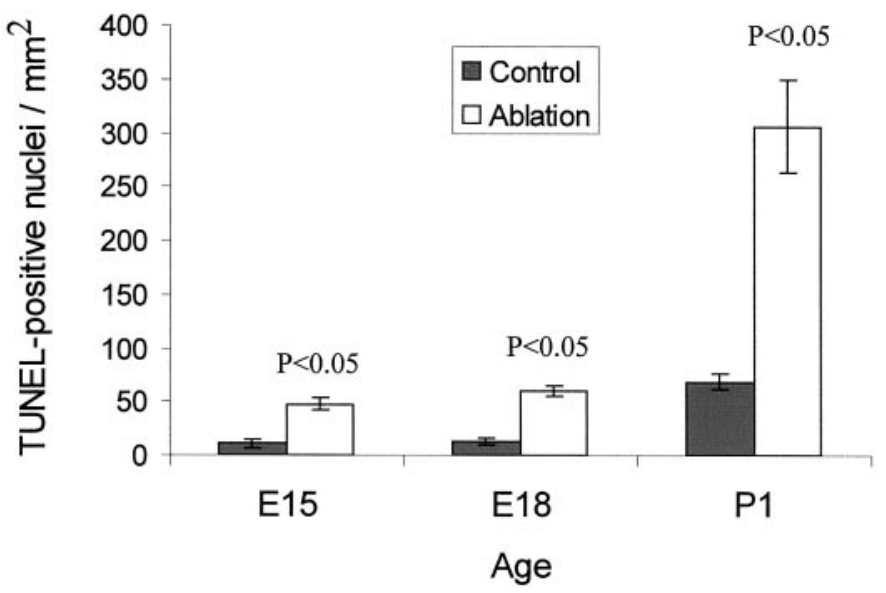

Figure 6. Increased cell death with the cerebral cortex of normal and ablated animals from E15 to P1. TUNEL+ nuclei were counted, and density measurements were performed on sections prepared from the brains as described in Materials and Methods. Error bars represent SEM. $n=8-12$ animals analyzed in each group at each age.

Table 1. Cortical thickness (in millimeters \pm SEM) of control and ablated brains at several ages

\begin{tabular}{lll} 
Age & Control & Ablation \\
\hline E18 & $0.64 \pm 0.02$ & $0.54 \pm 0.03^{*}$ \\
P1 & $0.73 \pm 0.01$ & $0.65 \pm 0.03^{*}$ \\
P4 & $0.98 \pm 0.06$ & $0.74 \pm 0.02^{*}$
\end{tabular}

$n=5-9$ animals analyzed in each group at each age, 15 sections measured per brain. ${ }^{*} p<0.05$.

death is evident in the ablated animals from E15 on, and, there appears to be a large increase in cell death in the cortex between E18 and P1. This increased cell death continues postnatally and precedes the onset of hydrocephaly by $\sim 10 \mathrm{~d}$.

\section{DISCUSSION}

Our results support several conclusions. (1) Specific reductions of cortical preplate cells can be achieved in a transgenic model using the golli promoter of the MBP gene to drive HSV-TK during early corticogenesis in the mouse. (2) Embryological ablation of preplate cells leads to an early disruption of the radial glial framework and subplate structure in the developing cortex, which, in turn, dramatically alter the cellular lamination and connectivity of the cortical plate. (3) Preplate cell ablation results in a severe postnatal cortical lesion resulting from the embryological insult and aggravated by the onset of secondary hydrocephaly.

\section{Advantages and selectivity of the genetic ablation approach}

We exploited previous findings that the golli promoter element of the MBP gene can target expression of transgenes to the preplate at very early stages of corticogenesis (Landry et al., 1998). We created a transgenic HSV-TK mouse that offered the advantage of a genetic ablation approach with greater specificity than previous methods. The expression of HSV-TK overlapped completely with that of the previously characterized lacZ gene, indicating a high degree of fidelity of the golli promoter in targeting transgene expression.

In studies using the HSV-TK gene, there is always the concern that "bystander" killing reduces the specificity of the ablation. In
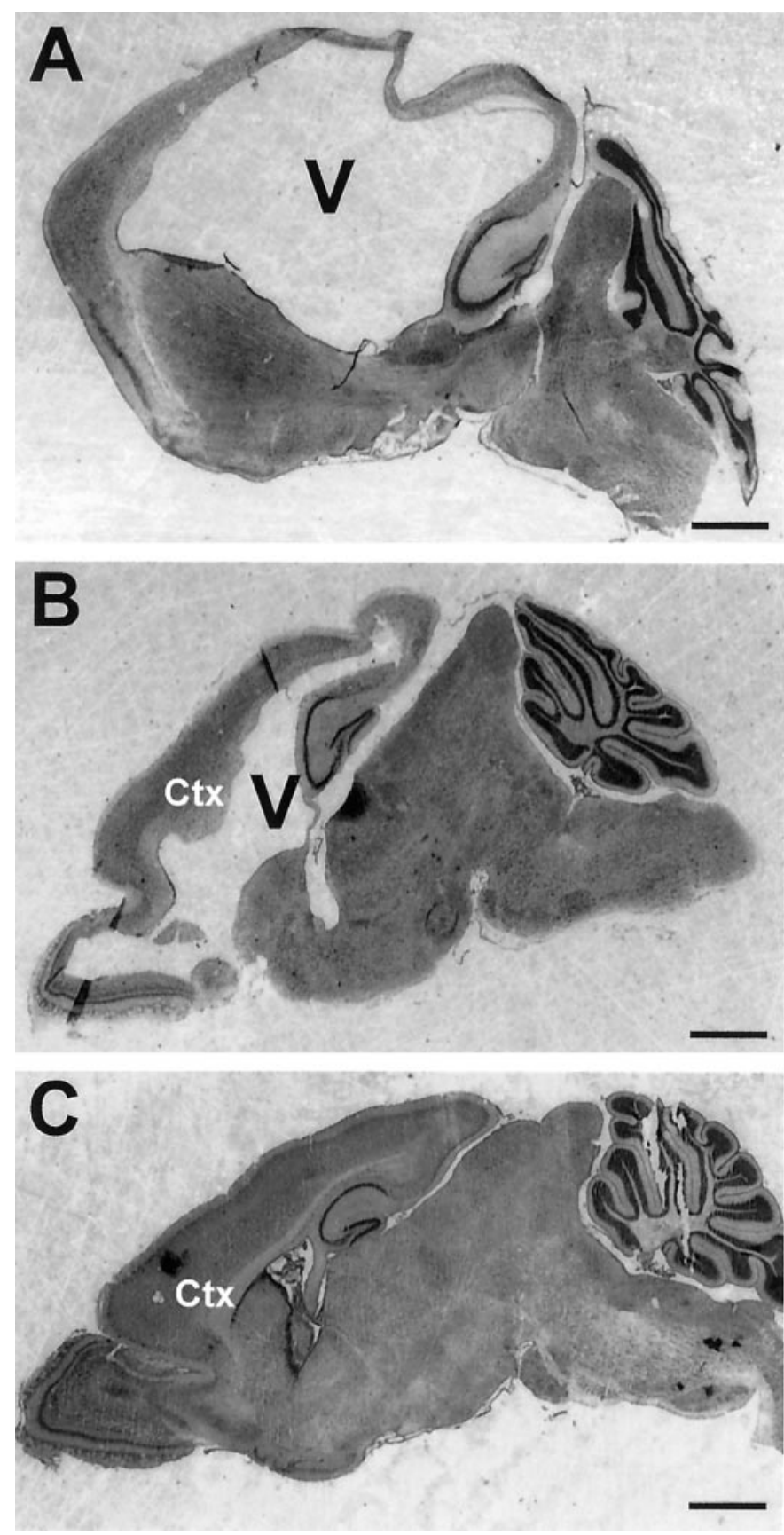

Figure 7. Development of postnatal lesion in HSV-TK+-ablated animals (parasagittal tissue sections; cresyl violet counterstain). $A$, Photomicrograph of brain from an ablated transgenic mouse at postnatal day 20. $B$, Photomicrograph of brain from an ablated mouse at postnatal day 14. $C$, Photomicrograph of brain from a control $(\mathrm{TK}-)$ wild-type mouse at postnatal day 20. Ctx, Cerebral cortex; $V$, lateral ventricle. Note the progressive dyslamination and thinning of cerebral cortex in the ablated mice compared with the wild-type control. The secondary effect of hydrocephaly is reflected in the gross and progressive ventricular enlargement, as well as the extreme end-stage thinning of the cerebral cortex itself in the TK + transgenic mice. Scale bar, $320 \mu \mathrm{m}$.

this instance, these concerns are minimal for several reasons. The susceptibility of adjacent cells to bystander killing has been directly related to the presence of gap junctions (to facilitate transfer of the toxic products of ganciclovir between cells) and the expression of connexins, the major components of gap junctions, 
by the cells. Whereas expression of the neuronal-specific connexin 36 has been reported in the developing mouse nervous system as early as E9-E10, it is not expressed in the telencephalic region giving rise to the cortical preplate (Gulisano et al., 2000). In fact, gap junctional profiles in rodent cerebral cortex have not been found by electron microscopy until $\sim$ E16, long after the administration of ganciclovir in this study (Nadarajah et al., 1997). A secondary cause of killing could be simple pinocytotic uptake of toxic ganciclovir products by adjacent cells. However, such a mechanism might be expected to produce unpredictable malformations of the preplate, such as patchy ripples of ablation in the preplate or a variable phenotype at later stages of cortical development. Such phenotypes were not evident. Another possibility is that dying cells produce an inflammatory response that might harm nearby cells. This possibility was excluded because we saw no evidence of edema or increased incidence of early-stage pyknotic nuclei in the ablated brains. Furthermore, given the normal background of cell death in the proliferative zone at the time of ganciclovir exposure (Blaschke et al., 1996, 1998), it is unlikely that such bystander killing contributed significantly to the pathological phenotype observed in the experimental mice.

The phenotype of the ablated animals was confined to the cortex and completely consistent with an early disruption of preplate neurons. In this regard, the golli promoter-driven HSV-TK gene, like the lacZ gene, was expressed in neurological sites other than the incipient preplate (Landry et al., 1998). Both transgenes were expressed by neurons in dorsal root ganglia of spinal nerves, spinal and cranial motor neurons, olfactory and gustatory epithelia, and olfactory bulbs. However, between E11 and E13, the primary target of the genetic ablation was the cortical preplate. With the exception of modest late-onset (postnatal) defects of olfactory bulb probably attributable to a side effect of the hydrocephaly, the potential target sites seemed to be intact and functional in the ablation animals.

Thus, this approach is particularly suited to studying corticogenesis for several reasons. The model permits the ablation of cortical pioneer neurons earlier than previous approaches. The ablation is transient, so postmitotic cells will be unaffected and continue to differentiate into Cajal-Retzius and subplate neurons. Finally, individual variation among animals subjected to the ablation conditions is minimized because the expression of the "suicide" gene is genetically determined in the appropriate cells, and control fetuses lacking the gene are exposed to exactly the same conditions as the experimental fetuses.

\section{Early ablation of preplate cells causes a cascade of events leading to disturbed cortical development}

In this study, the genetic ablation of significant numbers of preplate cells produced a fundamental perturbation of the developing cerebral cortex. Within hours of the last ganciclovir treatment, the ablated preplate was slightly thinner than controls. This was followed by a disturbance of the radial glial network, in terms of both the numbers and morphologies of the radial glia, probably through alterations of trophic and/or anchoring elements that guide its formation. Disruption of the radial glial network led to impaired neuronal migration from the ventricular zone into the growing cortical plate and the resultant dyslamination of the cortex. The extent to which migrating neurons reached their appropriate positions in the cortical plate might have depended on the integrity of the radial glia along which they migrated. There also was loss of a functional subplate resulting in the disruption of pioneering axons that establish cortico-cortico and cortico-fugal connectivity. This was manifest in fiber reduction within the cortex and disturbances of forebrain white matter structures, including the corpus callosum and internal capsule.

As noted, an immediate effect of preplate cell ablation was a disruption of the radial glial network and subsequent impairment of neuronal migration. This finding is consistent with the notion that Cajal-Retzius neurons, and perhaps subplate neurons, provide cues for the migrating neurons and support the radial glia scaffold for neurons migrating into the cortical plate from the germinal zone (Sheppard and Pearlman, 1997; Soriano et al., 1997; Marin-Padilla, 1998; Meyer et al., 2000). Although the mechanisms by which Cajal-Retzius cells are involved in neuronal migration are not clear, it has been suggested that these neurons might act on radial glial differentiation and attract migrating neurons through secretion of soluble factors (ChanasSacre et al., 2000).

It also has been suggested that Cajal-Retzius neurons may provide a "stop" signal that constrains migration of cortical plate neurons into the MZ (Ogawa et al., 1995; Del Rio et al., 1997; Marin-Padilla, 1998). Our ablation results do not support this notion because the loss of significant numbers of Cajal-Retzius cells did not result in opening the $\mathrm{MZ}$ to penetration by cortical plate neurons. Perhaps a near-complete elimination of CajalRetzius neurons would be necessary for such an outcome to occur. Thus, the effects on radial glia structure and neuronal migration observed in this study are consistent with the loss of Cajal-Retzius neurons at an early stage in corticogenesis.

The effects of the ablation on reduced cortical fibers and decreased thickness-fiber density in white matter structures is likely to be a direct consequence of a disturbance in the cortical subplate, which has been postulated to play a key role in the formation of cortico-cortico and cortico-fugal connections (Allendoerfer and Schatz, 1994; Soriano et al., 1994; Molnar and Blakemore, 1995; Molnar et al., 1998; Del Rio et al., 2000). Furthermore, the mislocation of neurons in the cortical plates of the ablated animals undoubtedly contributed to the dyslamination. The lack of appropriate targets for these neurons may have compromised their survival and accounted for the increased cell death noted in the cortices of the ablated animals. The inability of newly born neurons to exit the proliferative zones may account for the increased cell death noted in these regions during development. It should be noted that, even with a substantial ablation of preplate cells, the developmental program of cortical development was maintained.

\section{Early ablation of subplate cells results in a severe postnatal lesion}

The ablation of the preplate cells resulted in a later stage lesion and secondary, progressive hydrocephaly. It is likely that elevated cell death in the cortex and germinal zones contributed significantly to the thinning of the cortical plate and the formation of the lesion. We suggest that the marked increase in cortical cell death, particularly around birth, causes the degeneration of the cortex and the subsequent development of hydrocephaly, which may exacerbate the late-stage progression of the lesions in postnatal animals. We do not know the cause of the hydrocephaly, although it might result from cell debris retarding-blocking outflow of CSF. We were not able to identify a structural abnormality that would account for the hydrocephaly. We predict that the ablation conditions used in the present work can be "titrated" to produce less severe postnatal lesions and eliminate the secondary hydrocephaly. 
We believe that the transgenic ablation model described in this report offers great potential value for elucidating the morphogenic mechanisms of cerebral cortex development. The results outlined clearly underscore the critical importance of the preplate for the formation of the cortical plate, mediated through its guidance of the formation of radial glial scaffolding, subsequent neuronal migration into the incipient cortical plate, and the final arrangement of its vertical organization and cellular connectivity.

\section{REFERENCES}

Allendoerfer KL, Shatz CJ (1994) The subplate, a transient neocortical structure: its role in the development of connections between thalamus and the cortex. Annu Rev Neurosci 17:185-218.

Bayer SA, Altman J, Russo RJ, Dai XF, Simmons JA (1991) Cell migration in the rat embryonic neocortex. J Comp Neurol 307:499-516.

Blaschke AJ, Staley K, Chun J (1996) Widespread programmed cell death in proliferative and postmitotic regions of the fetal cerebral cortex. Development 122:1165-1174.

Blaschke AJ, Weiner JA, Chun J (1998) Programmed cell death is a universal feature of embryonic and postnatal neuroproliferative regions throughout the central nervous system. J Comp Neurol 396:39-50.

Bongarzone ER, Campagnoni CW, Kampf K, Jacobs EC, Handley VW, Schonmann V, Campagnoni AT (1999) Identification of a new exon in the myelin proteolipid protein gene encoding novel protein isoforms that are restricted to the somata of oligodendrocytes and neurons. J Neurosci 19:8349-8357.

Bongarzone ER, Byravan S, Givogri MI, Schonmann V, Campagnoni AT (2000) Platelet-derived growth factor and basic fibroblast growth factor regulate cell proliferation and the expression of Notch-1 receptor in a new oligodendrocyte cell line. J Neurosci Res 62:319-328.

Chanas-Sacre G, Rogister B, Moonen G, Leprince P (2000) Radial glia phenotype: origin, regulation, and transdifferentiation. J Neurosci Res 61:357-363.

das Neves L, Duchala CS, Tolentino-Silva F, Haxhiu MA, Colmenares C, Macklin WB, Campell CE, Butz KG, Gronostajski RM, Godinho F (1999) Disruption of the murine nuclear factor I-A gene (Nfia) results in perinatal lethality, hydrocephalus, and agenesis of the corpus callosum. Proc Natl Acad Sci USA 96:11946-11951.

Del Rio JA, Heinrich B, Borrel V, Forster E, Drakew A, Alcantara S, Nakajima K, Miyata T, Ogawa M, Mikoshiba K, Derer P, Frotscher M, Soriano E (1997) A role for Cajal Retzius cells and reelin in the development of hippocampal connections. Nature 385:70-74.

Del Rio JA, Martinez A, Auladell C, Soriano E (2000) Developmental history of the subplate and developing white matter in the murine neocortex. Neuronal organization and relationship with the main afferent systems at embryonic and perinatal stages. Cereb Cortex 10:784-801.

Ghosh A, Shatz CJ (1993) A role for subplate neurons in the patterning of connections from thalamus to neocortex. Development 117:1031-1047.

Gulisano M, Parenti R, Spinella F, Cicirata F (2000) Cx36 is dynamically expressed during early development of mouse brain and nervous system. NeuroReport 11:3823-3828.

Hevner RF, Shi L, Justice N, Hsueh YP, Sheng M, Smiga S, Bulfone A, Goffinet AM, Campagnoni AT, Rubenstein JLR (2001) Tbr1 regulates differentiation of the preplate and layer 6. Neuron 29:353-366.
Landry CF, Ellison JA, Pribyl TM, Campagnoni CW, Kampf K, Campagnoni AT (1996) Myelin basic protein gene expression in neurons: developmental and regional changes in protein targeting within neuronal nuclei, cell bodies, and processes. J Neurosci 16:2452-2462.

Landry CF, Pribyl TM, Ellison JA, Givogri MI, Kampf K, Campagnoni CW, Campagnoni AT (1998) Embryonic expression of the myelin basic protein gene: Identification of a promoter region that targets transgene expression to pioneer neurons. J Neurosci 18:7315-7327.

Lein ES, Finney EM, McQuillen PS, Shatz CJ (1999) Subplate neuron ablation alters neurotrophin expression and ocular dominance column formation. Proc Natl Acad Sci USA 96:13491-13495.

Marin-Padilla M (1998) Cajal-Retzius cells and the development of the neocortex. Trends Neurosci 21:64-71.

Meyer G, Schaaps JP, Moreau L, Goffinet AM (2000) Embryonic and early fetal development of the human neocortex. J Neurosci 20:1858-1868.

Molnar Z, Blakemore C (1995) How do thalamic axons find their way to the cortex? Trends Neurosci 18:389-397.

Molnar Z, Adams R, Giffinet AM, Blakemore C (1998) The role of the first postmitotic cortical cells in the development of the thalamocortical innervation in the Reeler mouse. J Neurosci 18:5746-5765.

Moolten FL (1986) Tumour chemosensitivity conferred by inserted herpes thymidine kinase genes: paradigm for a prospective cancer control strategy. Cancer Res 46:5276-5281.

Nadarajah B, Jones AM, Evans WH, Parnavelas JG (1997) Differential expression of connexins during neocortical development and neuronal circuit formation. J Neurosci 17:3096-3111.

Noctor SC, Palmer SL, Hasling T, Juliano S (1999) Interference with the development of early generated neocortex results in disruption of radial glia and abnormal formation of neocortical layers. Cereb Cortex 9:121-136.

Ogawa M, Miyata T, Nakajima K, Yagyu K, Seike M, Ikenaka K, Yamamoto H, Mikoshiba K (1995) The reeler gene-associated antigen in Cajal-Retzius neurons is a crucial molecule for laminar organization of cortical neurons. Neuron 14:899-912.

Roper SN (1998) In utero irradiation of rats as a model of human cerebral cortical dysgenesis: a review. Epilepsy Res 32:63-74.

Sheppard AM, Pearlman AL (1997) Abnormal reorganization of preplate neurons and their associated extracellular matrix: an early manifestation of altered neocortical development in the reeler mutant mouse. J Comp Neurol 38:173-179.

Soriano E, Del Rio JA, Martinez A, Super H (1994) Organization of the embryonic and early postnatal murine hippocampus. I. Immunocytochemical characterization of neuronal populations in the subplate and marginal zone. J Comp Neurol 342:571-595.

Soriano E, Alvarado-Mallart RM, Dumesnil N, Del Rio J, Sotelo C (1997) Cajal Retzius cells regulate the radial glia phenotype in the adult and developing cerebellum and alter granule cell migration. Neuron 18:563-577.

Stuart GW, Searle PF, Chen HY, Brinster RL, Palmiter RD (1984) A 12 -base-pair DNA motif that is repeated several times in metallothionein gene promoter confers metal regulation to a heterologous gene. Proc Natl Acad Sci USA 81:7318-7322.

Super H, Soriano E, Uylings HBM (1998) The functions of the preplate in development and evolution of the neocortex and hippocampus. Brain Res Rev 27:40-64.

Wood JG, Martin S, Price DJ (1992) Evidence that the earliest generated cell of the murine cerebral cortex form a transient population in the subplate and marginal zone. Dev Brain Res 66:137-140. 